\title{
How Occupational Mercury Neurotoxicity Is Affected by Genetic Factors. A Systematic Review
}

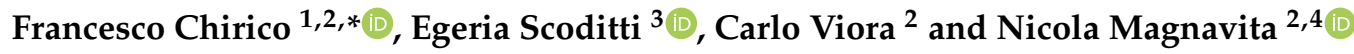 \\ 1 Health Service Department, Italian State Police, Ministry of Interior, 00184 Roma, Italy \\ 2 Section of Occupational Health and Labor Law of the Department of Life Sciences and Public Health, \\ Università Cattolica del Sacro Cuore, 00168 Roma, Italy; carlo.viora@unicatt.it (C.V.); \\ nicola.magnavita@policlinicogemelli.it (N.M.) \\ 3 National Research Council-Institute of Clinical Physiology (CNR-IFC), Lecce Unit, 73100 Lecce, Italy; \\ egeria.scoditti@ifc.cnr.it \\ 4 Department of Woman, Child and Public Health, Fondazione Policlinico Agostino Gemelli, 00168 Roma, Italy \\ * Correspondence: francesco.chirico@unicatt.it
}

Received: 11 September 2020; Accepted: 28 October 2020; Published: 30 October 2020

Featured Application: Existing studies on the association between certain polymorphisms and the appearance of neurotoxic effects in workers exposed to low doses of elemental mercury can provide physicians in charge of workers' health surveillance with tools to customize exposure monitoring.

\begin{abstract}
Occupational exposure to elemental mercury still represents a significant risk in the workplace. The sensitivity of the exposed subjects varies considerably. This study aims to summarize the literature on the role of genetic factors in occupationally exposed cohorts. A systematic search of the literature was carried out on PubMed Central (PMC), MEDLINE, and Google Scholar databases in accordance with the "Preferred Reporting Items for Systematic reviews and Meta-Analyses" (PRISMA) guidelines, from 1946 to July 2020. Ten cross-sectional studies were included in the review. All studies referred to the polymorphisms that can favour some neurotoxic effects of the metal in occupational cohorts. Some genetic variants may be associated with an increase in the occupational effects of mercury. Given the limited evidence, genetic screening of all mercury-exposed workers is not recommended. However, a personalized search for polymorphisms could be taken into consideration if exposed workers report early neurotoxic symptoms.
\end{abstract}

Keywords: polymorphism; occupational disease; workplace; prevention; personalized medicine; genetic screening; industrial hygiene; biological exposure index; goldminers; dental workers

\section{Introduction}

Elemental mercury $(\mathrm{Hg})$ is a naturally occurring toxic heavy metal [1]. It constitutes an important occupational risk by causing neurological, neuropsychological, cardiovascular, and other adverse effects in exposed workers [2]. This occupational risk has been well known for many centuries [3], and is still relevant for certain categories, such as dental technicians [4], miners [5,6], and other industrial workers [7-14]. Mercury is also an environmental toxicant whose effects on cell membranes have been well documented [15]. Global mercury production has steadily increased to reach approximately 4000 tons/year. In 2019, China was the world's largest producer, with a mine production volume of 3500 metric tons $[16,17]$. Disease associated with occupational mercury exposure is increasing globally, mainly as a consequence of small-scale mining activities [18]. 
Neurobehavioral deficits, including memory loss, mood changes, depression, anxiety, and motor dysfunction, have been associated with chronic occupational exposure to both high [19] and lower levels of $\mathrm{Hg}$ [20]. According to the literature, the neurotoxic effects of mercury are mainly due to alteration of the antioxidant system. A number of mechanisms, including signaling transduction, protein and/or enzyme activity, and gene regulation are involved in mediating toxic and adaptive response to mercury exposure [21].

Elemental $\mathrm{Hg}$, mainly found in the form of $\mathrm{Hg}$ vapor at room temperature, is absorbed via the lungs and distributed in the body via the blood, predominantly to the kidneys and the central nervous system. In the bloodstream, $\mathrm{Hg}$ is oxidized to its mercuric ion $(\mathrm{Hg} 2+)$ by the catalase enzyme. However, before oxidation, elemental $\mathrm{Hg}$ easily and rapidly passes through most cell membranes including the blood-brain barrier and the placenta. The urine and feces are the main excretory pathways of $\mathrm{Hg}$ in humans [22].

Although understanding of $\mathrm{Hg}$ toxicokinetic has improved, further studies are needed as regard its metabolism, interaction with other metals, distribution, internal doses and targets, and reservoir organs [23-26]. The influence of genetic factors on mercury toxicokinetic has been extensively studied and available research suggest that polygenic traits may contribute to the adverse Hg-mediated effects and to the variability in $\mathrm{Hg}$-associated risk $[27,28]$. Indeed, as molecular genetic techniques have advanced, DNA sequence variants referred to as polymorphisms (single nucleotide polymorphism SNP, deletion, insertion, copy number variations) have been increasingly recognized as important factors influencing human susceptibility to Hg-related outcomes. Allelic variations may determine functional differences in the level or activity of gene products involved in $\mathrm{Hg}$ toxicokinetic, as well as neurotoxic effects, thus potentially playing a role in $\mathrm{Hg}$ risk assessment.

Occupational risk prevention is based on the adoption of good working practices $[29,30]$ and the biological monitoring of workers. Mercury in whole blood (B-Hg) or urine (U-Hg) are commonly used to indicate exposure in occupational cohorts [31-33], while hair samples are preferred in general population studies [34]. B-Hg is considered a good indicator of recent exposure. U-Hg is an indicator of average exposure during the past month rather than exposure at the time of urine collection, when mercury burden has reached the steady state in occupationally exposed cohorts [32]. The American Conference of Governmental and Industrial Hygienists (ACGIH) recommends a biological exposure index (BEI) of $\mathrm{U}-\mathrm{Hg}$ in urine $<20 \mu \mathrm{g} / \mathrm{g}$ creatinine [35]. The knowledge of genetic determinants that could increase sensitivity to mercury could be very useful for detecting hypersensitive subjects.

The aim of this research was to systematically review the studies on the way genetic variants and polymorphisms can influence the neurotoxicity of mercury in occupational cohorts, in order to provide doctors responsible for the health surveillance of workers exposed to $\mathrm{Hg}$ with indications regarding the measures to be taken to prevent neurological damage.

\section{Research Question}

This study set out to discover whether genetic susceptibility affects the neurotoxicity mechanisms associated with occupational exposure to mercury and which genes polymorphisms may explain this type of association?

\section{Materials and Methods}

\subsection{Study Design}

Systematic review and meta-analysis

\subsection{Participants, Interventions, Comparators, Outcome (PICO)}

P: workers exposed to mercury. I: genetic susceptibility to mercury. C: workers with no genetic susceptibility to mercury. O: occupational neurotoxicity. 


\subsection{Systematic Review Protocol}

The study protocol for this research was registered on PROSPERO, on 14 August 2020 with the following number: CRD42020204372.

\subsection{Search Strategy}

A systematic search of the literature was carried out on PMC, MEDLINE, and Google Scholar databases in accordance with the "Preferred Reporting Items for Systematic reviews and Meta-Analyses" (PRISMA) guidelines, from 1946 to July 2020. The electronic search strategy for PubMed used MeSH terms related to the topic under investigation (Polymorphism, Genetic OR Genetic Predisposition to Disease OR Genotype OR Genetic Testing) in conjunction with mercury (Mercury OR Mercury Poisoning, Nervous System OR Mercury Poisoning), properly combined by Boolean operators. Only original studies in English were retrieved. Although review studies and commentaries were excluded from the present review, additional eligible studies were included after a hand-search of their reference lists.

\subsection{Data Sources and Data Extraction}

The principal criterion for eligibility was the presence of chronic occupational exposure to mercury and neurotoxicity. All studies that took into consideration genetic aspects of this relationship were included, whereas studies that did not consider genetic aspects were excluded. Similarly, studies that did not concern $\mathrm{Hg}$ neurotoxicity, or that considered environmental exposure in the community, were also excluded, as were studies involving exposure to methylmercury or other forms of organic mercury from food or drink, ecotoxicology studies, and studies on the general population exposed to sources of industrial pollution. Both experimental and observational studies with any design were screened for inclusion. Second level studies (review studies) were excluded, although they were examined to identify further research to be included in this review.

After independently reviewing all titles/abstracts, two authors (F.C. and C.V.) used the aforementioned inclusion/exclusion criteria to select studies on the basis of a full-text review. Disagreements were resolved by discussion with a third author (N.M.), who acted as the final referee.

Data concerning the country of study, job type, the study design, the type of gene polymorphisms observed, the methods of measurement, the confounding factors and the study's outcomes were extracted from each study. The authors carried out the data extraction process independently. The results of the studies were analysed qualitatively, and when possible, also quantitatively. The findings obtained were discussed by all the authors. Figure 1 illustrates the paper extraction flow diagram for this systematic review. 


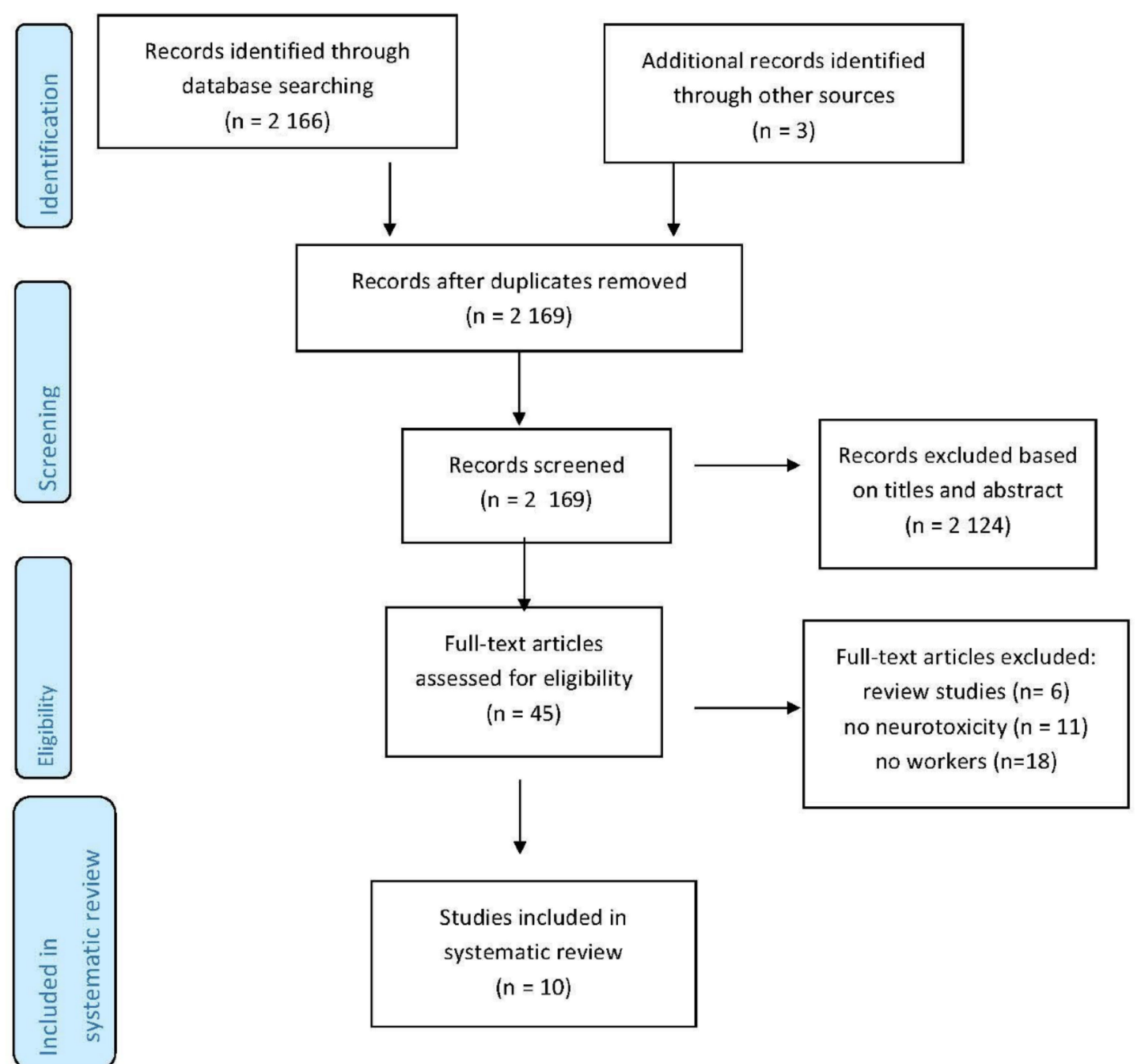

Figure 1. Article selection algorithm (PRISMA 2009).

\subsection{Study Quality Assessment}

The quality of cross-sectional studies was assessed using an adapted version of the Newcastle-Ottawa Quality Assessment Scale (NOS-A) for Case-Control/Cross-sectional studies [36] that awards a maximum score of 10 points.

\section{Results}

Research on databases resulted in a total of 2169 studies. After the removal of duplicates and studies that failed to meet the eligibility criteria, 45 full-text articles were retrieved. Of these, 11 studies were excluded because they did not concern neurotoxicity, and a further 18 were not included because they were not conducted on workers. Six literature reviews were also excluded. The final sample for systematic review consisted of 10 studies (Table 1). 
Table 1. Description of the studies included in the review $(n=10)$.

\begin{tabular}{|c|c|c|c|c|c|c|c|c|}
\hline Author (year) & Country & Population & Gene & Polymorphism & $\begin{array}{l}\text { Measurement } \\
\text { Instruments }\end{array}$ & $\begin{array}{c}\text { Average } \mathrm{Hg} \\
\text { Level (SD or } \\
\text { Range) }\end{array}$ & $\begin{array}{c}\text { Confounding } \\
\text { Factors }\end{array}$ & Main Findings \\
\hline $\begin{array}{l}\text { Heyer et al. } \\
\text { (2004) }\end{array}$ & USA & $\begin{array}{c}191 \text { male } \\
\text { dentists (DDs) } \\
\text { and } 230 \text { female } \\
\text { dental assistants } \\
\text { (DAs) }\end{array}$ & BDNF & $\begin{array}{l}\text { SNP }(G>A) \\
\text { resulting in the } \\
\text { substitution of } \\
\text { valine to } \\
\text { methionine at } \\
\text { codon } 66 \\
\text { (Val66Met) }\end{array}$ & $\begin{array}{l}\text { Spot urine samples } \\
\text { Buccal swabs for } \\
\text { genotyping. } \\
\text { Questionnaires }\end{array}$ & Not reported & $\begin{array}{c}\text { Age, race, } \\
\text { socioeconomic } \\
\text { status, tobacco and } \\
\text { alcohol use, self- } \\
\text { reported health } \\
\text { problems, } \\
\text { medications }\end{array}$ & $\begin{array}{l}\text { Val66Met polymorphism of } \\
\text { BDNF was associated with } \\
\text { increased symptom and } \\
\text { mood scores, in an } \\
\text { independent and additive } \\
\text { manner with Hg exposure }\end{array}$ \\
\hline $\begin{array}{l}\text { Echeverria } \\
\text { (2005) }\end{array}$ & USA & $\begin{array}{l}194 \text { DDs } 233 \\
\text { DAs }\end{array}$ & BDNF & $\begin{array}{c}\text { Val66Met } \\
\text { polymorphism }\end{array}$ & $\begin{array}{l}\text { Blood and urine } \\
\text { samples. } \\
\text { Buccal swab for } \\
\text { genotyping. } \\
\text { Questionnaires } \\
\text { Nerve Conduction } \\
\text { Velocity }\end{array}$ & $\begin{array}{c}\text { U-Hg: } 3.32 \pm \\
4.87 \mu \mathrm{g} / \mathrm{L}(\mathrm{DDs}) ; \\
1.98 \pm 2.29 \mu \mathrm{g} / \mathrm{L} \\
\text { (DAs) }\end{array}$ & $\begin{array}{l}\text { Age, alcohol } \\
\text { consumption } \\
\text { pre-morbid } \\
\text { intelligence, } \\
\text { education }\end{array}$ & $\begin{array}{l}\text { Val66Met polymorphism of } \\
\text { the BDNF was associated } \\
\text { with declines in performance } \\
\text { measures (working memory, } \\
\text { visual memory, and cognitive } \\
\text { flexibility), in an independent } \\
\text { and additive manner with } \\
\text { Hg exposure }\end{array}$ \\
\hline $\begin{array}{c}\text { Echeverria } \\
\text { (2006) }\end{array}$ & USA & $\begin{array}{l}194 \text { DDs } \\
233 \text { DAs }\end{array}$ & CPOX & $\begin{array}{l}\text { SNP }(A>C) \text { in exon } \\
4 \text { resulting in the } \\
\text { substitution of } \\
\text { asparagine to } \\
\text { histidine at codon } \\
272 \text { (Asn272His) }\end{array}$ & $\begin{array}{l}\text { Urine samples. } \\
\text { Buccal swab for } \\
\text { genotyping. } \\
\text { Questionnaires, } \\
\text { Visual Acuity and } \\
\text { vibration sensitivity }\end{array}$ & $\begin{array}{c}\text { U-Hg: } 3.32 \pm \\
4.87 \mu g / L \text { (DDs); } \\
1.98 \pm 2.29 \\
\mu \mathrm{g} / \mathrm{L} \text { (DAs) }\end{array}$ & $\begin{array}{l}\text { Age, alcohol } \\
\text { consumption, } \\
\text { premorbid } \\
\text { intelligence, } \\
\text { education. }\end{array}$ & $\begin{array}{l}\text { CPOX4 polymorphism was } \\
\text { associated with decline in } \\
\text { attention and visual memory } \\
\text { Independent and additive } \\
\text { effects for CPOX4 and Hg } \\
\text { exposure were observed on } \\
\text { visuomotor performance }\end{array}$ \\
\hline $\begin{array}{l}\text { Heyer et al. } \\
\text { (2008) }\end{array}$ & USA & $\begin{array}{l}157 \text { DDs, } \\
\text { 84 DAs }\end{array}$ & 5-HTT & $\begin{array}{l}\text { Insertion/deletion of } \\
44 \text { base pairs in the } \\
\text { polymorphic region } \\
\text { of the serotonin } \\
\text { transporter gene } \\
\text { (5-HTTLPR), }\end{array}$ & $\begin{array}{l}\text { Urine samples. } \\
\text { Buccal swab for } \\
\text { genotyping. } \\
\text { Questionnaires }\end{array}$ & $\begin{array}{c}\text { U-Hg: } 2.50 \pm \\
2.10 \mu \mathrm{g} / \mathrm{L}(\mathrm{DDs}) \\
1.06 \pm 1.07 \\
\mu \mathrm{g} / \mathrm{L} \text { (DAs) }\end{array}$ & $\begin{array}{c}\text { Age, socioeconomic } \\
\text { status, tobacco and } \\
\text { alcohol use, } \\
\text { self-reported health } \\
\text { problems, } \\
\text { medications. }\end{array}$ & $\begin{array}{l}\text { 5-HTTLPR polymorphism } \\
\text { (full mutation), but not } \mathrm{Hg} \\
\text { exposure, was associated } \\
\text { with increased symptoms of } \\
\text { depression, anxiety, and } \\
\text { memory. }\end{array}$ \\
\hline $\begin{array}{l}\text { Heyer et al. } \\
\text { (2009) }\end{array}$ & USA & $\begin{array}{l}183 \text { DDs } \\
213 \text { DAs }\end{array}$ & COMT & $\begin{array}{l}\text { SNP }(G>A) \\
\text { resulting in the } \\
\text { substitution of } \\
\text { valine to } \\
\text { methionine at } \\
\text { codon } 158 \\
\text { (Val158Met) }\end{array}$ & $\begin{array}{l}\text { Urine samples. } \\
\text { Buccal swab for } \\
\text { genotyping } \\
\text { Questionnaires }\end{array}$ & $\begin{array}{c}\text { U-Hg: } 2.39 \pm \\
2.08 \mu \mathrm{g} / \mathrm{L} \\
\text { (DDs); } 1.82 \pm \\
1.88 \mu \mathrm{g} / \mathrm{L} \text { (DAs) }\end{array}$ & $\begin{array}{l}\text { Age, socioeconomic } \\
\text { status, tobacco and } \\
\text { alcohol use, } \\
\text { self-reported health } \\
\text { problems, } \\
\text { medications. }\end{array}$ & $\begin{array}{l}\text { COMT polymorphism (full } \\
\text { mutation) was associated } \\
\text { with increased neurological } \\
\text { symptoms }\end{array}$ \\
\hline
\end{tabular}


Table 1. Cont

\begin{tabular}{|c|c|c|c|c|c|c|c|c|}
\hline Author (year) & Country & Population & Gene & Polymorphism & $\begin{array}{c}\text { Measurement } \\
\text { Instruments }\end{array}$ & $\begin{array}{c}\text { Average } \mathrm{Hg} \\
\text { Level (SD or } \\
\text { Range) }\end{array}$ & $\begin{array}{l}\text { Confounding } \\
\text { Factors }\end{array}$ & Main Findings \\
\hline $\begin{array}{l}\text { Echeverria } \\
\text { (2010) }\end{array}$ & USA & $\begin{array}{l}164 \text { DDs } 101 \\
\text { DAs }\end{array}$ & 5-HTT & $\begin{array}{l}\text { Insertion/deletion of } \\
44 \text { base pairs in the } \\
\text { polymorphic region } \\
\text { of the serotonin } \\
\text { transporter gene } \\
\text { (5-HTTLPR), }\end{array}$ & $\begin{array}{l}\text { Blood and urine } \\
\text { samples. } \\
\text { Buccal swab for } \\
\text { genotyping. } \\
\text { Questionnaires. } \\
\text { Visual acuity. } \\
\text { Vibration } \\
\text { sensitivity. }\end{array}$ & $\begin{array}{c}\text { U-Hg: } 2.52 \pm \\
2.22 \mu \mathrm{g} / \mathrm{L}(\mathrm{DDs}) \\
1.98 \pm 1.98 \\
\mu \mathrm{g} / \mathrm{L} \\
\text { (DAs) }\end{array}$ & $\begin{array}{l}\text { Age, premorbid } \\
\text { intelligence, } \\
\text { frequency of alcohol } \\
\text { per week, and } \\
\text { education. }\end{array}$ & $\begin{array}{l}\text { The 5-HTTLPR } \\
\text { polymorphism was } \\
\text { associated with decline in } \\
\text { cognitive flexibility and } \\
\text { manual coordination, } \\
\text { working memory and visual } \\
\text { memory, and reaction time. }\end{array}$ \\
\hline $\begin{array}{l}\text { Wang et al. } \\
\text { (2012) }\end{array}$ & USA & $\begin{array}{l}244 \text { DDs and } \\
\text { DAs } \\
269 \\
\text { non-dentists. }\end{array}$ & proteins & SNPs & $\begin{array}{l}\text { Hair and urine } \\
\text { samples. } \\
\text { Buccal swab for } \\
\text { genotyping. } \\
\text { Hand diagrams, } \\
\text { Nerve conduction } \\
\text { function }\end{array}$ & U-Hg: $1.06 \mu \mathrm{g} / \mathrm{L}$ & $\begin{array}{l}\text { Age, gender race, } \\
\text { occupation, height, } \\
\text { weight, dominant } \\
\text { hand, hand } \\
\text { temperature and } \\
\text { foot temperature. }\end{array}$ & $\begin{array}{l}\text { There is no sufficient } \\
\text { evidence of effect } \\
\text { modification of the studied } \\
\text { SNPs/deletion } \\
\text { polymorphisms on the } \\
\text { relationship between nerve } \\
\text { function and mercury burden } \\
\text { in the body. }\end{array}$ \\
\hline $\begin{array}{l}\text { Harari } \\
(2012)\end{array}$ & Ecuador & $\begin{array}{l}200 \text { gold miners } \\
37 \text { gold } \\
\text { merchants }\end{array}$ & GCLC-129 & $\begin{array}{c}\text { SNPs in GCLC-129 } \\
\text { GCLM-588, } \\
\text { GSTP1-105, } \\
\text { GSTP1-114 }\end{array}$ & $\begin{array}{c}\text { Urine samples. } \\
\text { Whole blood for } \\
\text { genotyping. } \\
\text { Neurobehavioural } \\
\text { test }\end{array}$ & $\begin{array}{l}\text { U-Hg: } 37 \\
(3.2-420) \mu \mathrm{g} / \mathrm{g} \text { in } \\
\text { gold merchants. } \\
3.3(0.23-170) \\
\mu \mathrm{g} / \text { gin gold } \\
\text { miners }\end{array}$ & $\begin{array}{c}\text { Age, smoking, } \\
\text { alcohol, amalgam } \\
\text { fillings, } \\
\text { fish consumption. }\end{array}$ & $\begin{array}{l}\text { SNP of GCLM was } \\
\text { associated with B-Hg and } \\
\text { U-Hg levels. No clear } \\
\text { association of SNP and Hg } \\
\text { levels with neurotoxicity. }\end{array}$ \\
\hline $\begin{array}{c}\text { Chernyak } \\
\text { (2013) }\end{array}$ & Russia & 116 men & $\begin{array}{l}\text { GSTT1, } \\
\text { GSTM1 }\end{array}$ & Deletion & $\begin{array}{l}\text { Blood samples for } \\
\text { genotyping. } \\
\text { Urine samples for } \\
\text { the antipyrine } \\
\text { elimination test. }\end{array}$ & Not reported & $\begin{array}{l}\text { Smoking status } \\
\text { (cotinine levels) }\end{array}$ & $\begin{array}{l}\text { In patients with diagnosed } \\
\text { chronic mercury intoxication, } \\
\text { the disease progression is } \\
\text { related to inhibition of } \\
\text { cytochrome P450 isoforms in } \\
\text { combination with high } \\
\text { frequency of } \\
\text { GSTT1(0/0)/GSTM1(+) } \\
\text { genotype }\end{array}$ \\
\hline $\begin{array}{l}\text { Kolbinger } \\
\text { (2019) }\end{array}$ & $\begin{array}{c}\text { Philippines, } \\
\text { Indonesia, } \\
\text { Tanzania, } \\
\text { Zimbabwe }\end{array}$ & 558 goldminers & $\mathrm{ABCC} 2$ & SNPs in ABCC2 & $\begin{array}{l}\text { Urine samples. } \\
\text { Whole blood for } \\
\text { genotyping. } \\
\text { Self-reported } \\
\text { questionnaire }\end{array}$ & $\begin{array}{l}\mathrm{U}-\mathrm{Hg} \text { from } 2.0 \\
(0.2-20) \text { to } 29 \\
(2.3-210) \mu \mathrm{g} / \mathrm{g} \text { in } \\
\text { high exposure } \\
\text { national groups }\end{array}$ & $\begin{array}{l}\text { Age, gender, fish } \\
\text { consumption }\end{array}$ & $\begin{array}{c}\text { ABCC2 polymorphism } \\
\text { (alleles in rs2273697 and } \\
\text { rs1885301) was associated } \\
\text { with worse performance on } \\
\text { neurological tests. }\end{array}$ \\
\hline
\end{tabular}




\section{Study Selection and Characteristics}

All studies had a cross-sectional design. The quality of studies was mainly moderate to low (ranging from 2 to 7 on the 10-point NOS-A scale). The studies were conducted mainly in the USA; one study was performed by the Global Mercury Project (GMP) implemented by the United Nations Industrial Development Organization (UNIDO) in developing countries, one in Ecuador, and one study was carried out in Russia. Six of the 7 American studies were conducted on the same cohort of dental workers, selected between 1998 and 2001 and composed of 193 male dentists and 230 female dental assistants belonging to the Washington State Dental Association with an average of 18 years of Hg-related exposure. The participants in the other American study were recruited during the Michigan Dental Association (MDA) annual conventions held in $2009(\mathrm{n}=232)$ and $2010(\mathrm{n}=283)$. The Russian study was performed on 116 men chronically exposed to metallic $\mathrm{Hg}$ in 2005-2006 and 2009-2010. The UNIDO studies were based on $558 \mathrm{Hg}$-exposed workers in Asia and Africa. The Ecuadorian study recruited 200 miners and 37 gold merchants. Quantitative meta-analytical analyzes could not be performed due to the modest size of the case series, the overlapping of observations, and the use of a number of confounding. The studies included in our review examined some $\mathrm{Hg}$ neurotoxicity mechanisms in order to identify genetic variations related to neurotoxicity. Different genes were taken into consideration. To date, no study has checked the results of previous studies.

The studies we examined did not consider the bio-metabolism of mercury and the genes that can influence its absorption, distribution, or excretion. They focused on variations that can favour some neurotoxic effects of the metal. Their aim was to detect individual factors that may influence sensitivity to Hg-mediated effects, due to polymorphisms within genes that are known to influence the same neurobehavioral functions that are adversely impacted by $\mathrm{Hg}$ exposure.

US studies on the Washington cohort focused on early neurobehavioral effects (mood and symptoms) associated with elemental mercury exposures among dental practitioners. A weighted chronic mercury exposure index was created for participants by adding together the contribution of each of their reported dental-related jobs, and a weighting factor based on the time-period of the job. An acute cumulative mercury exposure index based on urinary mercury was also calculated. Subjects underwent neuropsychological testing and reported symptoms.

The studies investigated single nucleotide polymorphisms (SNPs) of some genes that code for proteins essential for the central nervous system. The first target studied was the Brain-Derived Neurotrophic Factor (BDNF), a protein that regulates neuronal growth and differentiation in the peripheral and central nervous system [37], whose secretion and processing can be altered by an SNP (G196A) leading to the substitution of valine (val) with methionine (met) in the BDNF gene at codon 66 (val66met). In measurement of memory, the BDNF polymorphism has been linked to abnormal hippocampal activation and reduced performance [38-40]. Neurological effects in US workers exposed to $\mathrm{Hg}$ were associated with BDNF status, with a joint additive effect of $\mathrm{Hg}$ exposure and BDNF polymorphism reported for some neurological measurements. The results obtained in these dental workers in relation to mood and symptoms in 2004 [41] were confirmed the following year in a slightly increased number of cases regarding the effect on cognitive and motor performance scores [42].

Subsequently, the same research group described an SNP (A814C) in exon 4 resulting in an asparagin to histidine substitution at codon 272 (asn272his) of the gene encoding the heme biosynthetic pathway enzyme, coproporphyrinogen oxidase (CPOX), which significantly modifies the effect of $\mathrm{Hg}$ exposure on urinary porphyrin excretion in humans. Indeed, this polymorphism exacerbates an abnormal urinary porphyrin excretion pattern associated with mercury exposure [43]. Hence, they examined the neurobehavioral consequences of this polymorphism ("CPOX4") in dental professionals, showing a limited effect on neurobehavioral performance, attention and mood, that is independent (not interactive) and additive with $\mathrm{Hg}$ exposure on visuomotor performance [44]. This means that, when occurring simultaneously, $\mathrm{Hg}$ exposure and the presence of the polymorphism increased the overall adverse outcome. 
Another aspect of mercury neurotoxicology that has been investigated is the uptake of serotonin. An insertion/deletion polymorphism in the polymorphic region of the serotonin transporter (5-HTT) gene (SLC6A4) located on chromosome 17q11, termed serotonin transporter gene-linked polymorphic region (5-HTTLPR), has the potential to regulate the level of the functional serotonin transporter. Compared to the long (" 1 ") allele (wild-type), the short allele (" $\mathrm{s}$ " polymorphism) has been found to halve serotonin uptake [45], and this has been associated with the presence of anxiety, depression, affective states, and other mental health problems in humans $[46,47]$. In a preliminary study, the analysis of data from a subsample of the Washington cohort of dental workers showed that 5-HTTLPR polymorphism with full mutation (ss) was associated with increased self-reported symptoms of depression, anxiety and memory, but no significant interactions between $\mathrm{Hg}$ exposure and the 5-HTTPLR polymorphism were found [48]. In a subsequent study, exposure to $\mathrm{Hg}$ and the presence of the 5-HTTLPR polymorphism independently altered behavioral performance and mood state [49]. Some neurobehavioral domains were additively affected by both $\mathrm{Hg}$ exposure and the genetic variant.

A transcriptional substitution of methionine for valine at codon 158 of the gene encoding for Catechol O-methyltransferase (COMT), an important enzyme in the methylation of endogenous and exogenous catechol compounds, including catecholamine neurotransmitters and estrogens, results in decreased enzymatic activity compared with the wild-type allele of the gene, and has been related with changes in cognitive function and affective responses (REF). In the Washington cohort, several types of symptoms were associated with both $\mathrm{Hg}$ exposure and COMT polymorphism, especially full mutation (two Met158 alleles) suggesting a gene-dose effect [50].

Another US study was performed on a sample of 515 dental workers (dentists, dental hygienists, and dental assistants) of the Michigan Dental Association, recruited in 2009 and 2010. Subjects provided urine and hair samples for $\mathrm{Hg}$ measurement, performed measurement of sensory nerve conduction, and completed a hand symptom diagram for carpal tunnel syndrome. Genotyping for 15 SNPs from selenoprotein and glutathione-related genes along with 13 metallothionein SNPs was performed. Most of these polymorphisms had been previously reported [51] or hypothesized to significantly modify Hg effects in humans, since they were related to genes involved in $\mathrm{Hg}$ metabolism or functioning as antioxidants. The complex set of relationships investigated led to the creation of 504 multivariate linear regression models predicting nerve function, of which only 3 indicated a significant SNP-Hg level interaction, specifically for glutathione peroxidase 1 (GPX1), metallothionein 1E (MT1E), and glutamate cysteine ligase catalytic subunit (GCLC). The authors concluded that there was little evidence that the SNPs studied modified the effect of the relationship between nerve function and mercury burden in the body [52].

The Russian study was conducted in Siberia on 116 men recruited in two phases (2005-2006 and 2009-2010), all of whom had been exposed to mercury for a long period (>10 years) and most of whom were affected by current or past chronic Hg intoxication. Cytochrome P450-dependent monooxygenase (CYP) activity plays a key role in the metabolism of xenobiotic and endogenous substrates. In the brain, it contributes to cholesterol turnover, and the metabolism of neurotransmitters and steroids, and is also involved in the pathogenesis of neurodegenerative diseases [53]. Hg is known to inhibit CYP activity. In the Russian study, the metabolism of antipyrine, an indicator of cytochrome P450 activity that is inhibited by mercury, and the distribution of polymorphic variants of GSTT1 (glutathione S-transferase theta 1) and GSTM1 (glutathione S-transferase mu 1) genes, known to influence $\mathrm{Hg}$ metabolism, were studied. The GSTT1(0/0)/GSTM1(+) genotype was more frequent in intoxicated subjects, in parallel with the inhibition of CYP activity. The authors concluded that the suppression of cytochrome P450-dependent monooxygenase in the brain had probably favored the intoxication [54].

The United Nations studies recruited 558 gold miners from 4 developing countries, considering 18 SNPs in $8 \mathrm{Hg}$-transporter genes and more specifically ATP-binding cassette transporters (ABC transporters), which influence $\mathrm{Hg}$ toxicokinetics. $\mathrm{ABCC} 2$ alleles were associated with worse neurological performance $[55,56]$. These studies suggest that certain ABCC2 polymorphisms may influence neurotoxic effects in mercury-burdened individuals. The polymorphism in a gene of an 
enzyme in the glutathione synthesis (GCLM) was associated with B-Hg and U-Hg concentrations in Ecuadorian miners and gold merchants, but no interaction was found between polymorphism and neurological changes [57].

\section{Discussion}

Taken as a whole, the studies retrieved for this review suggest that polymorphisms in candidate genes may affect susceptibility for specific neurobehavioral functions associated with occupational $\mathrm{Hg}$ exposure. Occupational findings add to existing evidence indicating genetic determinants of mood and behavior that potentially increase susceptibility to $\mathrm{Hg}$ toxicity in human subjects. However, occupational studies have made only a modest contribution to understanding the adverse effects of elemental mercury. To date, no studies have investigated the role that genetic factors may play in the absorption, distribution, and excretion of mercury, and most genes are selected by authors based on criteria of biological plausibility and their role in neurological outcomes. The body burden of mercury in workers has been estimated on the basis of the duration and time of exposure, mainly by integrating these data with the $\mathrm{Hg}$ dosage in a single urine sample. No studies have measured mercury in tissues. The demonstration of an association between a polymorphism and neurobehavioral alterations, mood, or potentially neurotoxic symptoms cannot be considered evidence if it has not been confirmed by other studies replicating previous observations on the same genetic variant. Since the studies included in this review mostly attempted to identify new variants instead of examining previous findings from other candidate gene studies, it was not possible to pool results to categorically ascertain the influence of a genetic variant. Most of the studies were performed in Caucasian, or predominantly Caucasian populations, or did not report the ethnicity of participants. Consequently, the frequency of allele variations across ethnic groups could not be evaluated [58]. An evaluation of the findings was further limited due to the fact that the studies retrieved did not always consider the same confounding factors and included factors potentially influencing the results, such as ethnicity, alcohol, health status, as well as diet; this is a further limitation to the evaluation of the findings. Furthermore, published studies were not of high quality, particularly when specific methods for genetic studies were used for assessment [59]. Research findings demonstrate the difficulties encountered in reproducing behavioral or symptomatic results for very low exposures in different populations and with changing explanatory variables. Clearly, further studies are needed to confirm or disprove the associations observed and to investigate numerous other genetic factors that could be associated with the toxic effects of mercury in workers.

However, the limited number of available studies that have been included in this systematic review indicate that adverse neurobehavioral effects may be associated with occupational elemental mercury exposures similar to those experienced by the general population due to mercury amalgam dental fillings, or other environmental pollution sources. Occupational studies therefore have an important significance for public health.

Studies on occupational cohorts such as workers exposed to mercury in the same workplace could easily be carried out by an occupational health and safety service. The medical health surveillance of workers and their biological monitoring would be much more efficient if they could incorporate elements of genetics to promptly identify polymorphisms that increase the risk of neurological damage. Employers may have a legitimate interest in funding studies on the genetic status of their employees, in order to limit the exposure of hypersensitive individuals, who could be harmed even if exposed to levels not exceeding the permissible standard. Concern for both occupational and public health should encourage governments to intervene to fund or promote prevention in this area. Studies conducted by the United Nations on gold-working artisans in the Philippines, Indonesia, Tanzania, and Zimbabwe point in the right direction and should be followed by interventions to improve the conditions of these workers.

Unfortunately, the increase in occupational exposure to mercury, as recorded throughout the world, principally involves developing countries or those in which industrial development takes place 
without due regard for Western health and safety standards. In such countries, the clinical and genetic evaluation of workers is undoubtedly difficult, as is demonstrated in Siberia where even the type of work activity is unknown.

The difficulty of being able to study an occupational cohort exposed to significant levels of mercury vapor, added to the complexity, invasiveness and cost of the tests required have limited research. Dental workers, who were willing to undergo the complex analyses needed to identify pre-clinical alterations, have gradually adopted measures to reduce their occupational exposure. Dental exposure to mercury has fallen significantly over the last few decades. Consequently, mean urinary mercury concentrations in dentists are currently approaching levels observed in the general population. The difference between the positive findings of the Washington cohort, recruited in 1999, and the negative results in the more recent Michigan sample, indicates the current difficulty in obtaining a sample of high-dose exposed and available workers in Western countries.

Previous studies in non-occupational settings have provided sufficient evidence of the role of SNPs in Hg toxicity. These studies, however, focus mainly on organic mercury that has a different toxicological profile from that of the elemental metal. For example, maternal polymorphisms in glutathione-related genes were associated with maternal mercury concentrations and early child neurodevelopment in a population with a fish-rich diet [60]. Genetic polymorphisms of catechol-O-methyltransferase were found to modify the neurobehavioral effects of mercury in children [61], and an increased susceptibility to the adverse neurobehavioral effects of $\mathrm{Hg}$ was found among children with relatively common genetic variants of metallothionein [62]. While levels of mercury exposure have fallen in industries (at least in developed countries), the accumulation of $\mathrm{Hg}$ in biota and its biomagnification in aquatic food chains pose a real threat to public health $[63,64]$. Recent studies have shown that increasing concentrations of inorganic $\mathrm{Hg}$ may be present in the brain of relatively low exposure subjects as they get older, and that the pattern of $\mathrm{Hg}$ deposition in the brain tissues of individuals exposed to environmental pollution is different from that of workers with acute or subacute exposures to lethal or significantly higher concentrations in workplaces [65]. The spread of this neurotoxic metal in the environment and its bioaccumulation in the food chain are leading to epigenetic consequences [66]. Other neurotoxic metals, such as aluminum, may be present in the environment [67], and this can definitively increase the risk for occupationally exposed workers. Future occupational studies will need to take these important factors into account.

The limitations of our review are clearly related to some aspects of the occupational studies: observations are derived from only three research groups; they are only cross-sectional, conducted on small groups and do not take into account all the numerous confounding factors and possible impact of linkage disequilibrium. The presence of these limitations is also the main merit of the work done since it underlines the need for further research into the gene-environment interaction in a sector of great interest for public health.

\section{Conclusions}

Occupational studies indicate that certain genetic variants may be associated with increased effects of mercury on workers. This data, which would seem obvious on the basis of research on the general population, has so far had little corroboration from studies conducted in the workplace. The evidence gathered to date is weak and is not sufficient to support the adoption of genetic screening techniques before the hiring of workers who will be exposed to inorganic mercury. Nevertheless, current indications concerning the association between certain polymorphisms and more serious effects in some subjects should lead doctors in charge of occupational health surveillance to propose carrying out personalized genetic tests for workers who report early symptoms or signs of neurological or neuropsychological impairment.

Because there is now greater awareness of the environmental risk of mercury, of the interactions with other neurotoxicants and of its epigenetic effects, more attention should be given to working populations in which industrial risk is added to ecological one. In this perspective, internationally 
sponsored studies on workers in developing countries must promote the adoption of timely prevention measures in these occupational sectors. If multicenter studies on the topic should confirm the associations reported, numerous companies could gradually include genetic tests in their medical examination protocol that would obviously continue to respect all the principles of confidentiality and worker protection. In this way, the prevention of occupational risk could be personalized and become more effective than prevention based only on environmental values. This type of research would be of particular value, since the effects observed often occur in individuals exposed to doses close to those of the general population. Consequently, studies on workers would provide useful elements to protect the health of the entire population.

Author Contributions: Conceptualization, F.C. and N.M.; methodology, F.C. and N.M.; validation, F.C., N.M., and E.S.; formal analysis, F.C.; investigation, C.V.; resources, E.S.; data curation, C.V.; writing-original draft preparation, F.C.; writing—review and editing, N.M.; supervision, E.S.; project administration, N.M. All authors have read and agreed to the published version of the manuscript.

Funding: This research received no external funding.

Acknowledgments: We thank Elizabeth Ann Wright who revised the language.

Conflicts of Interest: The authors declare no conflict of interest.

\section{References}

1. Bernhoft, R.A. Mercury toxicity and treatment: A review of the literature. J. Environ. Public Health 2012, 2012, 1-10. [CrossRef] [PubMed]

2. Clarkson, T.W.; Magos, L. The toxicology of mercury and its chemical compounds. Crit. Rev. Toxicol. 2006, 36, 609-662. [CrossRef] [PubMed]

3. Ramazzini, B. The Disease of Workers (De Morbis Artificum Diatriba, 1700-1713). In Ramazzini B. Works; Cierre Edizioni: Verona, Italy, 2009.

4. Bjørklund, G.; Hilt, B.; Dadar, M.; Lindh, U.; Aaseth, J. Neurotoxic effects of mercury exposure in dental personnel. Basic Clin. Pharmacol. Toxicol. 2019, 124, 568-574.

5. Kristensen, A.K.; Thomsen, J.F.; Mikkelsen, S. A review of mercury exposure among artisanal small-scale gold miners in developing countries. Int. Arch. Occup. Environ. Health 2014, 87, 579-590. [CrossRef] [PubMed]

6. Afrifa, J.; Opoku, Y.K.; Gyamerah, E.O.; Ashiagbor, G.; Sorkpor, R.D. The Clinical Importance of the Mercury Problem in Artisanal Small-Scale Gold Mining. Front. Public Health 2019, 29, 131. [CrossRef]

7. Wrbitzky, R.; Göen, T.; Letzel, S.; Frank, F.; Angerer, J. Internal exposure of waste incineration workers to organic and inorganic substances. Int. Arch. Occup. Environ. Health 1995, 68, 13-21. [CrossRef]

8. El-Sayed, L.H.; Ghoneim, H.M.; El-Sayed, M.H.; Deimian, S.R.; Adam, A.N.; Abou Rawash, S.N.; Abou Rawash, N.M.; Ursos, P. Immunological abnormalities in workers exposed to pollutants at an Egyptian copper company. Immunopharmacol. Immunotoxicol. 2003, 25, 473-490. [CrossRef]

9. Fierens, S.; Mairesse, H.; Heilier, J.F.; Focant, J.F.; Eppe, G.; De Pauw, E.; Bernard, A. Impact of iron and steel industry and waste incinerators on human exposure to dioxins, PCBs, and heavy metals: Results of a cross-sectional study in Belgium. J. Toxicol. Environ. Health A 2007, 70, 222-226. [CrossRef]

10. Neghab, M.; Norouzi, M.A.; Choobineh, A.; Kardaniyan, M.R.; Zadeh, J.H. Health effects associated with long-term occupational exposure of employees of a chlor-alkali plant to mercury. Int. J. Occup. Saf. Ergon. 2012, 18, 97-106. [CrossRef]

11. Wang, J.; Hayes, J.; Wu, C.Y.; Townsend, T.; Schert, J.; Vinson, T.; Deliz, K.; Bonzongo, J.C. Characterization of vapor phase mercury released from concrete processing with baghouse filter dust added cement. Environ. Sci. Technol. 2014, 48, 2481-2487. [CrossRef]

12. Ceballos, D.; Beaucham, C.; Page, E. Metal Exposures at three U.S. electronic scrap recycling facilities. J. Occup. Environ. Hyg. 2017, 14, 401-408. [CrossRef] [PubMed]

13. Darvishi, E.; Assari, M.J.; Farhadian, M.; Chavoshi, E.; Ehsani, H.R. Occupational exposure to mercury vapor in a compact fluorescent lamp factory: Evaluation of personal, ambient air, and biological monitoring. Toxicol. Ind. Health 2019, 35, 304-313. [CrossRef] [PubMed] 
14. Bagheri Hosseinabadi, M.; Khanjani, N.; Mobarake, M.D.; Shirkhanloo, H. Neuropsychological effects of long-term occupational exposure to mercury among chloralkali workers. Work 2020, 66, 491-498. [CrossRef] [PubMed]

15. Reznikoff, P. Micrurgical studies in cell physiology: Ii. The action of the chlorides of Lead, Mercury, Copper, Iron, and Aluminum on the protoplasm of amoeba proteus. J. Gen. Physiol. 1926, 10, 9-21. [CrossRef] [PubMed]

16. USGS United States Geological Survey Mineral Commodity Summary for 2020. Available online: https: //www.usgs.gov/centers/nmic/mercury-statistics-and-information (accessed on 9 September 2020).

17. Statista. Mercury Production Worldwide in 2019, by Country. Available online: https://www.statista.com/ statistics/1005602/global-mercury-production-by-country/ (accessed on 9 September 2020).

18. Steckling, N.; Tobollik, M.; Plass, D.; Hornberg, C.; Ericson, B.; Fuller, R.; Bose-O'Reilly, S. Global Burden of Disease of Mercury Used in Artisanal Small-Scale Gold Mining. Ann. Glob. Health 2017, 83, $234-247$. [CrossRef]

19. Zhou, Z.; Zhang, X.; Cui, F.; Liu, R.; Dong, Z.; Wang, X.; Yu, S. Subacute motor neuron hyperexcitability with mercury poisoning: A case series and literature review. Eur. Neurol 2014, 72, 218-222. [CrossRef]

20. Calabrese, E.J.; Iavicoli, I.; Calabrese, V.; Cory-Slechta, D.A.; Giordano, J. Elemental mercury neurotoxicity and clinical recovery of function: A review of findings, and implications for occupational health. Environ. Res. 2018, 163, 134-148. [CrossRef]

21. Yang, L.; Zhang, Y.; Wang, F.; Luo, Z.; Guo, S.; Strähle, U. Toxicity of mercury: Molecular evidence. Chemosphere 2020, 245, 125586. [CrossRef]

22. World Health Organization. Elemental Mercury and Inorganic Mercury Compounds: Human Health Aspects; Concise International Chemical Assessment Document 50; World Health Organization: Geneva, Switzerland, 2003. Available online: https://www.who.int/ipcs/publications/cicad/en/cicad50.pdf (accessed on 9 September 2020).

23. Bjørklund, G.; Dadar, M.; Mutter, J.; Aaseth, J. The toxicology of mercury: Current research and emerging trends. Environ. Res. 2017, 159, 545-554. [CrossRef]

24. Abass, K.; Huusko, A.; Knutsen, H.K.; Nieminen, P.; Myllynen, P.; Meltzer, H.M.; Vahakangas, K.; Rautio, A. Quantitative estimation of mercury intake by toxicokinetic modelling based on total mercury levels in humans. Environ. Int. 2018, 114, 1-11. [CrossRef]

25. Syversen, T.; Kaur, P. The toxicology of mercury and its compounds. J. Trace Elem. Med. Biol. 2012, 26, 25-26. [CrossRef]

26. Spiller, H.A. Rethinking mercury: The role of selenium in the pathophysiology of mercury toxicity. Clin. Toxicol. 2018, 56, 313-326. [CrossRef] [PubMed]

27. Llop, S.; Ballester, F.; Broberg, K. Effect of Gene-Mercury Interactions on Mercury Toxicokinetics and Neurotoxicity. Curr. Environ. Health Rep. 2015, 2, 179-194. [CrossRef] [PubMed]

28. Andreoli, V.; Sprovieri, F. Genetic Aspects of Susceptibility to Mercury Toxicity: An Overview. Int. J. Environ. Res. Public Health 2017, 14, 93. [CrossRef] [PubMed]

29. Guthrie, G.; Dilworth, M.; Sen, D. Reducing mercury exposure in fluorescent lamp manufacture-A workplace case study. J. Occup. Environ. Hyg. 2006, 3, D15-D18. [CrossRef] [PubMed]

30. Ngim, C.; Ngim, A.D. Health and safety in the dental clinic-Hygiene regulations for use of elemental mercury in the protection of rights, safety and well-being of the patients, workers and the environment. Singap. Dent. J. 2013, 34, 19-24. [CrossRef] [PubMed]

31. Barregård, L. Biological monitoring of exposure to mercury vapor. Scand. J. Work Environ. Health 1993, 19, $45-49$.

32. Apostoli, P.; Mangili, A.; Alessio, L. Significance of biological indicators of mercury exposure. Med. Lav. 2003, 94, 231-241.

33. Tuček, M.; Bušová, M.; Čejchanová, M.; Schlenker, A.; Kapitán, M. Exposure to mercury from dental amalgam: Actual contribution for risk assessment. Cent. Eur. J. Public Health 2020, 28, 40-43. [CrossRef]

34. Li, P.; Guo, S.; Zhao, J.; Gao, Y.; Li, Y.F. Human Biological Monitoring of Mercury Through Hair Samples in China. Bull. Environ. Contam. Toxicol. 2019, 102, 701-707. [CrossRef] 
35. American Conference of Governmental and Industrial Hygienists (ACGIH). TLVs and BEIs Threshold Limit Values for Chemical Substances and Physical Agents and Biological Exposure Indices; American Conference of Governmental Industrial Hygienists: Cincinnati, OH, USA, 2017. Available online: https://www.acgih.org (accessed on 28 September 2020).

36. Modesti, P.A.; Reboldi, G.; Cappuccio, F.P.; Agyemang, C.; Remuzzi, G.; Rapi, S.; Perruolo, E.; Parati, G.; ESH Working Group on CV risk in low resource settings. Panethnic differences in blood pressure in europe: A systematic review and meta-analysis. PLoS ONE 2016, 11, e0147601. [CrossRef]

37. Burkhalter, J.; Fiumelli, H.; Allaman, I.; Chatton, J.Y.; Martin, J.L. Brain-derived neurotropic factor stimulates energy metabolism in developing cortical neurons. J. Neurosci. 2003, 23, 8212-8220. [CrossRef] [PubMed]

38. Egan, M.F.; Kojima, M.; Callicott, J.H.; Goldberg, T.E.; Kolachana, B.S.; Bertolino, A.; Zaitsev, E.; Gold, B.; Goldman, D.; Dean, M.; et al. The BDNF val66met polymorphism affects activity dependent secretion of BDNF and human memory and hippocampal function. Cell 2003, 112, 257-269. [CrossRef]

39. Hariri, A.R.; Goldberg, T.E.; Mattay, V.S.; Kolachana, B.S.; Callicott, J.H.; Egan, M.F.; Weinberger, D.R. Brain-derived neurotrophic factor val66met polymorphism affects human memory-related hippocampal activity and predicts memory performance. J. Neurosci. 2003, 23, 6690-6694. [CrossRef] [PubMed]

40. Marx, J. Neuroscience. Minor variation in growth-factor gene impairs human memory. Science 2003, 299, 639-640. [CrossRef] [PubMed]

41. Heyer, N.J.; Echeverria, D.; Bittner, A.C., Jr.; Farin, F.M.; Garabedian, C.C.; Woods, J.S. Chronic Low-Level Mercury Exposure, BDNF Polymorphism, and Associations with Self-reported Symptoms and Mood. Toxicol. Sci. 2004, 81, 354-363. [CrossRef] [PubMed]

42. Echeverria, D.; Woods, J.S.; Heyer, N.J.; Rohlman, D.S.; Farin, F.M.; Bittner, A.C., Jr.; Li, T.; Garabedian, C. Chronic low-level mercury exposure, BDNF polymorphism, and associations with cognitive and motor function. Neurotoxicol. Teratol. 2005, 27, 781-796. [CrossRef] [PubMed]

43. Woods, J.S.; Echeverria, D.; Heyer, N.J.; Simmonds, P.L.; Wilkerson, J.; Farin, F.M. The association between genetic polymorphisms of coproporphyrinogen oxidase and an atypical porphyrinogenic response to mercury exposure in humans. Toxicol. Appl. Pharmacol. 2005, 206, 113-120. [CrossRef]

44. Echeverria, D.; Woods, J.S.; Heyer, N.J.; Rohlman, D.; Farin, F.M.; Li, T.; Garabedian, C.E. The association between a genetic polymorphism of coproporphyrinogen oxidase, dental mercury exposure and neurobehavioral response in humans. Neurotoxicol. Teratol. 2006, 28, 39-48. [CrossRef]

45. Lesch, K.-P.; Bengel, D.; Heils, A.; Sabol, S.Z.; Greenberg, B.D.; Petri, S.; Benjamin, J.; Muller, C.R.; Hamer, D.H.; Murphy, D.L. Association of anxiety-related traits with a polymorphism in the serotonin transporter gene regulatory region. Science 1996, 274, 1527-1531. [CrossRef]

46. Yoshida, K.; Ito, K.; Sato, K.; Takahashi, H.; Kamata, M.; Higuchi, H.; Shimizu, T.; Itoh, K.; Inoue, K.; Tezuka, T.; et al. Influence of the serotonin transporter gene-linked polymorphic region on the antidepressant response to fluvoxamine in Japanese depressed patients. Prog. Neuropsychopharmacol. Biol. Psychiatry 2002, 26, 383-386. [CrossRef]

47. Zalsman, G.; Huang, Y.; Oquendo, M.A.; Burke, A.K.; Hu, X.; Brent, D.A.; Ellis, S.P.; Goldman, D.; Mann, J.J. Association of a triallelic serotonin transporter gene promoter region (5-HTTLPR) polymorphism with stressful life event and severity of depression. Am. J. Psychiatry 2006, 163, 1588-1593. [CrossRef] [PubMed]

48. Heyer, N.J.; Echeverria, D.; Farin, F.M.; Woods, J.S. The Association Between Serotonin Transporter Gene Promoter polymorphism (5-HTTLPR), Self-Reported Symptoms, and Dental Mercury Exposure. J. Toxicol. Environ. Health 2008, 19, 1318-1326. [CrossRef]

49. Echeverria, D.; Woods, J.S.; Heyer, N.J.; Martin, M.D.; Rohlman, D.S.; Farin, F.M.; Li, T. The association between serotonin transporter gene promotor polymorphism (5-HTTLPR) and elemental mercury exposure on mood and behavior in humans. J. Toxicol. Environ. Health A 2010, 73, 1003-1020. [CrossRef]

50. Heyer, N.J.; Echeverria, D.; Martin, M.D.; Farin, F.M.; Woods, J.S. Catechol O-Methyltransferase (COMT) VAL158MET Functional Polymorphism, Dental Mercury Exposure, and Self-Reported Symptoms and Mood. J. Toxicol. Environ. Health A 2009, 72, 599-609. [CrossRef]

51. Custodio, H.M.; Harari, R.; Gerhardsson, L.; Skerfving, S.; Broberg, K. Genetic influences on the retention of inorganic mercury. Arch. Environ. Occup. Health 2005, 60, 17. [CrossRef]

52. Wang, Y.; Goodrich, J.M.; Werner, R.; Gillespie, B.; Basu, N.; Franzblau, A. An investigation of modifying effects of single nucleotide polymorphisms in metabolism-related genes on the relationship between peripheral nerve function and mercury levels in urine and hair. Sci. Total Environ. 2012, 417-418, 32-38. [CrossRef] 
53. Navarro-Mabarak, C.; Camacho-Carranza, R.; Espinosa-Aguirre, J.J. Cytochrome P450 in the central nervous system as a therapeutic target in neurodegenerative diseases. Drug Metab. Rev. 2018, 50, 95-108. [CrossRef] [PubMed]

54. Chernyak, Y.I.; Itskovich, V.B.; D'yakovich, O.A.; Kolesnikov, S.I. Role of Cytochrome P450-Dependent Monooxygenases and Polymorphic Variants of GSTT1 and GSTM1 Genes in the Formation of Brain Lesions in Individuals Chronically Exposed to Mercury. Bull. Exp. Biol. Med. 2013, 156, 21-25. [CrossRef] [PubMed]

55. Engström, K.; Ameer, S.; Bernaudat, L.; Drasch, G.; Baeuml, J.; Skerfving, S.; Bose-O’Reilly, S.; Broberg, K. Polymorphisms in genes encoding potential mercury transporters and urine mercury concentrations in populations exposed to mercury vapor from gold mining. Environ. Health Perspect. 2013, 121, 85-91. [CrossRef]

56. Kolbinger, V.; Engström, K.; Berger, U.; Bose-O’Reilly, S. Polymorphisms in potential mercury transporter ABCC2 and neurotoxic symptoms in populations exposed to mercury vapor from goldmining. Environ. Res. 2019, 176, 108512. [CrossRef] [PubMed]

57. Harari, R.; Harari, F.; Gerhardsson, L.; Lundh, T.; Skerfving, S.; Strömberg, U.; Broberg, K. Exposure and toxic effects of elemental mercury in gold-mining activities in Ecuador. Toxicol. Lett. 2012, 213, 75-82. [CrossRef] [PubMed]

58. Thomas, D.C.; Witte, J.S. Point: Population stratification: A problem for case-control studies of candidate-gene associations? Cancer Epidemiol. Biomark. Prev. 2002, 11, 505-512.

59. Sohani, Z.N.; Meyre, D.; de Souza, R.J.; Joseph, P.G.; Gandhi, M.; Dennis, B.B.; Norman, G.; Anand, S.S. Assessing the quality of published genetic association studies in meta-analyses: The quality of genetic studies (Q-Genie) tool. BMC Genet. 2015, 16, 50. [CrossRef]

60. Wahlberg, K.; Love, T.M.; Pineda, D.; Engstrom, K.; Watson, G.E.; Thurston, S.W.; Yeates, A.J.; Mulhern, M.S.; McSorley, E.M.; Strain, J.J.; et al. Maternal polymorphisms in glutathione-related genes are associated with maternal mercury concentrations and early child neurodevelopment in a population with a fish-rich diet. Environ. Int. 2018, 115, 142-149. [CrossRef] [PubMed]

61. Woods, J.S.; Heyer, N.J.; Russo, J.E.; Martin, M.D.; Pillai, P.B.; Bammler, T.K.; Farin, F.M. Genetic polymorphisms of catechol-O-methyltransferase modify the neurobehavioral effects of mercury in children. J. Toxicol. Environ. Health A 2014, 77, 293-312. [CrossRef] [PubMed]

62. Woods, J.S.; Heyer, N.J.; Russo, J.E.; Martin, M.D.; Pillai, P.B.; Farin, F.M. Modification of neurobehavioral effects of mercury by genetic polymorphisms of metallothionein in children. Neurotoxicol. Teratol. 2013, 39, 36-44. [CrossRef]

63. Horvat, M.; Nolde, N.; Fajon, V.; Jereb, V.; Logar, M.; Lojen, S.; Jacimovic, R.; Falnoga, I.; Liya, Q.; Faganeli, J.; et al. Total mercury, methylmercury and selenium in mercury polluted areas in the province Guizhou, China. Sci. Total Environ. 2003, 304, 231-256. [CrossRef]

64. Gong, Y.; Nunes, L.M.; Greenfield, B.K.; Qin, Z.; Yang, Q.; Huang, L.; Bu, W.; Zhong, H. Bioaccessibility-corrected risk assessment of urban dietary methylmercury exposure via fish and rice consumption in China. Sci. Total Environ. 2018, 630, 222-230. [CrossRef]

65. O’Donoghue, J.L.; Watson, G.E.; Brewer, R.; Zareba, G.; Eto, K.; Takahashi, H.; Marumoto, M.; Love, T.; Harrington, D.; Myers, G.J. Neuropathology associated with exposure to different concentrations and species of mercury: A review of autopsy cases and the literature. Neurotoxicology 2020, 78, 88-98. [CrossRef]

66. Ijomone, O.M.; Ijomone, O.K.; Iroegbu, J.D.; Ifenatuoha, C.W.; Olung, N.F.; Aschner, M. Epigenetic influence of environmentally neurotoxic metals. Neurotoxicology 2020, 81, 51-65. [CrossRef]

67. Alexandrov, P.N.; Pogue, A.I.; Lukiw, W.J. Synergism in aluminum and mercury neurotoxicity. Integr. Food Nutr. Metab. 2018, 5, 10. [CrossRef] [PubMed]

Publisher's Note: MDPI stays neutral with regard to jurisdictional claims in published maps and institutional affiliations. 